\title{
Fractured Childhoods, Identities in Transit: Humanitarian Aid for Central European Refugees from the United Kingdom
}

\author{
Magdalena Garrido Caballero \\ Universidad de Murcia, \\ Dpto. Historia Moderna, Contemporánea, de América, del Pensamiento y los Movimientos Sociales y Políticos \\ e-mail: mgarridocaballero@um.es \\ ORCID iD: http://orcid.org/0000-0001-7468-5960
}

Submitted: 18 May 2018. Accepted: 24 March 2019

\begin{abstract}
The aim of this study is to address the situation of one of the most vulnerable social collectives: Central European refugee children and youths who fled the territories occupied by the Third Reich, thanks to the help provided by large number of private or public organizations, which resulted in the reception of about ten thousand refugees in the United Kingdom at the beginning of World War II. To this end, diverse documents have been analysed from archives such as The National Archive and The British Library, in order to learn more about this human drama and its impact upon international politics, as well as the role played by the British Government.
\end{abstract}

KEYWORDS: Refugees; Humanitarian aid; Europe; International Relations; Testimonies; Cultural identity; 20th century history.

Citation / Cómo citar este artículo: Garrido Caballero, Magdalena (2019) "Fractured Childhoods, Identities in Transit: Humanitarian Aid for Central European Refugees from the United Kingdom”. Culture \& History Digital Journal, 8 (2): e023. https://doi.org/10.3989/chdj.2019.023

RESUMEN: Infancias rotas, identidades en tránsito. La ayuda humanitaria a los refugiados centroeuropeos desde Reino Unido.- El objeto de estudio de este artículo es abordar la situación de uno de los colectivos más vulnerables, el de niños y jóvenes refugiados centroeuropeos que emprendieron la huida de los territorios ocupados por el III Reich, a través de la ayuda proporcionada por un gran número de organizaciones de carácter privado o estatal, que llevó a la recepción de unos diez mil refugiados menores de edad en Reino Unido al inicio de la Segunda Guerra Mundial. Con este fin, se ha analizado documentación diversa procedente de archivos como The National Archive y la British Library, para acercarnos a ese drama humano y conocer su impacto en la política internacional, así como el papel desempeñado por el gobierno británico.

PALABRAS CLAVE: Refugiados; Ayuda humanitaria; Europa; Política internacional; Testimonios; Identidad cultural; Historia del siglo XX.

Copyright: (C) 2019 CSIC. This is an open-access article distributed under the terms of the Creative Commons Attribution 4.0 International (CC BY 4.0) License. 
After the impact of the Kristallnacht, the night of broken glass, an expression of anti-Semitism against Jewish citizens, their properties and synagogues, which took place on the night of November 9-10, 1938 in Germany and Austria, there was a major shift in the British attitude towards the effects of the anti-Semitic laws of the III Reich. A year earlier, appeals had been issued to accept refugees, following the Nazi bombing of Guernica in April 1937. However, the evacuation of children from the Basque Country was perceived as a possible crack in the non-intervention policy adopted by the British Government (Bell, 2007). Both the actions related to the humanitarian appeals to relieve the children's suffering (Wilson and Brown, 2009) and the reception of refugees by the United Kingdom can be included in the era of "imperial humanitarianism", which spans from the late- $18^{\text {th }}$ century until the end of the Second World War (Barnett, 2011). This article focuses, specifically, on the experience of the human aid directed at central European refugees taken in by the UK in the 1930s.

Since the first anti-Semitic measures adopted by the Nazis, organizations, mainly Jewish had issued appeals for help and warned of the dramatic consequences that the application of such measures was having for the nonAryan population.

In July 1938, at the initiative of the United States President Franklin D. Roosevelt, a conference had been organised in Évian-les-Bains (France) ${ }^{1}$ in order to analyse the situation of the Jewish refugees who were victims of the Nazi policy. Thirty-two countries participated, but it turned out to be unsuccessful, since most countries made excuses not to receive refugees, except for the Dominican Republic. With regard to the British stance on the issue, Prime Minister S.E. Baldwin was asked in Parliament on November 21, 1938, about the progress made in the policy of receiving refugees. He replied that the established guidelines were being followed and reported on the limitations that they faced:

The number of refugees which Great Britain can agree to admit, either for a temporary stay or for permanent settlement, is limited by the capacity of the voluntary organisations dealing with the refugee problem to undertake the responsibility for selecting, receiving and maintaining a further number of refugees. His Majesty's Government are keeping in close touch with the Committee which has been set up to co-ordinate the activities of the voluntary organisations engaged upon this task. The United Kingdom has, since 1933, permitted about 11,000 men, women and children to land in this country, in addition to some 4,000 or 5,000 others who have since emigrated overseas.

As regards the Colonial Empire, it must be remembered that, although covering a great extent of territory, it is not necessarily capable of the immediate absorption of large numbers of refugees. $[\ldots]^{2}$

In spite of following a policy of appeasement of Nazi Germany in the international arena and the signing of the Munich Pact in September 1938, two months later, the British government joined the aid effort to move to the United Kingdom an unspecified number of endangered minor children and adolescents, from territories occupied by the Third Reich in Central Europe, for a period of two years with educational purposes, at no expense to the British taxpayer. This fact illustrates the success of the activism of various individuals and organisations that represented the spirit of "internationalism" after the First World War (Gorman, 2012) in the face of the indifference and harassment they were subjected to at the hands of pro-Nazi sectors such as the British Union of Fascists, dissolved by government order in 1940 .

In December, the Prime Minister, made an appeal on the radio for the British population to donate the fiftypound bond necessary for the children's transfer (Roth, 2004). Along the same lines, year later, in early 1939, U.S. Senators Robert Wagner and Edith Rogers proposed a draft law in immigration policy in order to allow for the arrival of 20,000 children from Germany (most of them Jewish). This proposal was the subject of much debate and was ultimately rejected on the grounds that "Charity begins at home" (Breitman and Kraut, 1987). This truncated initiative prevented the saving of more lives.

In this context of radicalization of anti-Semitic policies, occupation of territories by Nazi Germany and the reluctant attitude of countries in Europe and America towards the reception of refugees, is situated the British experience in providing aid to young refugees, paradigmatic since it is a model in which Government and charities worked to the same end: to save children and young people from occupied Europe. This led to what was known as Kindertransport. The term refers to the evacuation of minors who went by train from different points of Czechoslovakia, Germany and Austria to ports, mainly in Holland, from where they sailed for the United Kingdom. The evacuations included around 10,000 young people between 1938 and 1939. But, in an extensive way, as pointed out by Vera Fast (2011), it would also include organisation of transport in the post-war period in order to take to Great Britain children who survived the concentration camps or remained hidden during the Second World $W^{3}{ }^{3}$. Therefore, it is a broader process in time that is part of the history of child exile and the survivors of the Holocaust.

The paper trail of the Kindertransports has been fragmented and dispersed owing to the numerous non-profit, Jewish and Christian organizations, private sponsors and public institutions that participated in the rescue and reception once they arrived in the United Kingdom. Among the most relevant documentary evidence, the actual documentation produced by Nicholas Winton, actively involved in the rescue of children, and bequeathed to Yad Vashem ${ }^{4}$. To the latter one must add very diverse documents kept in archives and in Britain and other countries. In this study the records held at The National Archives, especially the Health Department reports on the situation of host establishments ${ }^{5}$ have been particularly valuable. Also, the interviews gathered in the oral collections of the 
British Library, the sources provided by the Kindertransport Association that unites the refugee children that escaped from the Holocaust with their descendants and promotes aid for children ${ }^{6}$. There are also documentaries, the main one being Into the Arms of Strangers: Stories of the Kindertransport (Mark Jonathan Harris, 2000) ${ }^{7}$. As well as the press that focused on the story decades later and the specialized bibliography (Chadwick, 2010; Fast, 2011; Williams, 2012) amongst others, which enriches the pages of this text.

The humanitarian aid provided by volunteers, organizations and institutions offered a different destiny to the children in danger, the hope of future for many families, doomed to a suffocating atmosphere future of deprivation of liberty, uncertainty and anguish. That help brings us closer to truncated lives, broken childhoods in transit to another country, with a different language and culture to which it was necessary to adapt. It was not easy, neither for the refugees nor for the organizations that had to overcome many difficulties, not just in terms of funding, but of criteria, as for the most orthodox Jewish organizations it was a priority that children should be placed within Jewish families and observe their customs, although the criterion that prevailed was to save those who were at a higher risk and greater hardship. In this article, the story and the memories of those evacuated by the Kindertransports connects with the experience of what is known as "humanitarian culture", understood as a myriad of actions led by activists and countries that contributed to improving the situation of the refugees in a particular historical context. Their imprint upon the present makes it possible to explore more deeply the emotions of the participants (Febvre, 1950; Zaragoza, 2013; Plamper, 2013) and situations like the ones described by this testimony:

I was about 8 years old when Hitler came to power.

I had got some school friends and my mother tried to make a birthday party for us.

The table was set. I was very excited. Nobody came. Not a single child came to this birthday party.

That was the first terrible blow to me. I know it sounds trivial but it was the first sort of comprehension for a child to understand that you're ostracized. That there's something different about you.

For Jewish children life under Hitler became increasingly isolated and threatening.

While the Nazis stripped their parents of their jobs and citizenship the children were gradually barred from schools, parks, theatres, and swimming pools.

While the Nazis stripped their parents of their jobs and citizenship the children were gradually barred from schools, parks, theatres, and swimming pools. I was overprotected because of the Hitler dangers outside the home ${ }^{8}$.

This testimony also reminds historians that, according to Watenpaugh (2015), they should not lose sight of their own humanity and should use it as a tool to deploy their empathetic imagination in their work when they come across so much hatred, violence and loss.

\section{BROKEN CHILDHOODS. THE RESCUE OF CENTRAL EUROPEAN CHILDREN AND YOUNG PEOPLE FROM THE NAZIS THROUGH THE KINDERTRANSPORTS}

The testimony reflects the situation in which the nonAryan population found itself through the eyes of a girl who had been deprived of her rights. This situation occurred not only in Germany but also in the occupied territories. The organization of the Kindertransports brought together many organizations that operated in different countries and helped to carry out the rescue, especially of children, such as the British Committee for the Jews of Germany and the Movement for the Care of Children from Germany, which, in 1939, would merge with the Refugee Children's Movement (RCM, conglomerate of agencies $)^{9}$, among others, together with citizens who individually participated in the reception and provided financial support in the interest of their education and well-being. The British government allowed the arrival of young children unaccompanied by their parents, for this, they needed a temporary visa, a medical certificate and a fiftypound guarantee for education, and the commitment to facilitate their return home when the crisis ended.

The first Kindertransport arrived in December 1938. It consisted of some 200 children from a Jewish orphanage in Berlin after the Kristallnacht pogrom. The children left by train from Berlin, Vienna, Prague and other cities of Central Europe. The first Children's transport from Vienna took place on December 10, and the last from Germany on September 1, 1939. On May 14, the last crossing was made from Holland, now occupied by the German troops.

In the case of Czechoslovakia, the annexation of the Sudetenland by the Third Reich, which was recognized in the Munich Pact (1938) by the European powers in an international context of application of the appeasement policy, prompted a crisis for refugees, stranded in numerous camps on the outskirts of Prague. Individuals and organizations saw in situ the human drama of the exiles and were especially concerned about the situation of children. In this work, Doreen Warrener ${ }^{10}$ stood out in particular. She worked for the British Committee for Refugees in Czechoslovakia $^{11}$, "and their job was to bring out those people who were being, or would be endangered by the Germans"12. It was not the only organization present in the country (the SAM's Committee, the Lord Mayor's Committee, the Quakers, the Unitarians, etc.) but those who collaborated with it were notable for support they gave to the families when their little ones departed. Nicholas Winton participated in this work. After receiving a call from his friend Martin Blake, he cancelled a holiday trip to Switzerland and checked the situation of refugees in Czechoslovakia ${ }^{13}$. In his words: Well, it was just a lot of people living in, in rather claustrophobic conditions, in Nissen huts ${ }^{14}$. That sight led him to participate in the evacuation of children. With the help of Trevor Chadwick $^{15}$ and other collaborators, he organized the rescue of some 669 children from Czechoslovakia, the so-called 
"Winton Children"16. Winton's work consisted of unifying the different lists provided by the aid organizations and making appeals to the British press to find sponsors, paying attention to the urgent cases. For the evacuation they needed two cards, one for the Inter-Aid Committee, as a travel card and another for the Home Office (with a favourable response from Home Secretary Samuel Hoare, Quaker, at the head of Neville Chamberlain's government). Regional committees proliferated in Manchester, Birmingham, Bristol, Cambridge, Battersea (South London) and Foster Parents and hostels were sought to house them.

The children's transports left from Czechoslovakia. The first train left on the very day before the Germans invaded Prague and the remaining parts of Czechoslovakia, on March 15, 1939. However, several previous evacuations had already taken place. In January, two flights left from Prague; one bound for Sweden with a few little children. And during that same month, another known as the "Hansi Neumann Flight". Hansi was the three-year-old boy with whom Winton appeared in a photo taken at the airport which had quite an impact in the media. That travel was sponsored by the Barbican Mission and involved the rescue of around sixty children. The children arrived in Croydon and stayed in Brockley. In the background were the family members who had come to say their farewells. The story of this rescue had a sad ending for Hansi, who died of an ear infection and whose parents disappeared in the concentration camps (Chadwick, 2010: 44-46).

Winton returned to London after his holiday leave, which he was unable to extend for as long as he hoped. According to William Chadwick, this happened on January 21,1939 . From his home country he continued with the aid, for which he created the British Committee for Refugee Children from Czechoslovakia (BCRC). His assistants in Great Britain were Barbara Willis, future wife of his friend Martin Blake, and W. H. Loewinshon, who was making the scrapbook that Winton kept in his home. Their activity focused on locating host families or institutions that could take care of the children ${ }^{17}$. If someone showed interest in six-year-old girls, they sent photos and data of several girls of similar age to be chosen and welcomed into families. To achieve his purpose, he wrote in the press in order to sensitize the population and find host families while thousands were left behind in Czechoslovakia.

Trevor Chadwick continued to help from Prague, along with Bill Barazetti, who worked for the Czech secret service. Negotiating train departures with the Nazi authorities or creating false documents (Gershon, 1966: 33). And so Gay Felds recalls his work in The Guardian:

It was Chadwick who was stationed in Prague and had to select the children (the British guarantors who paid $£ 50$ for the privilege mostly wanted girls aged seven to 10 and, if possible, fair-haired) and organised their trav$\mathrm{el}$, at first by plane, later by train. It was he who, on one occasion, when the Home Office made no effort to supply the necessary papers in the limited timeframe, was forced to find someone to forge documents to enable the children to leave. He even managed to save some adults, smuggled through as "leaders". [...]
Felds explains: It is sad that he and Doreen Warriner are largely forgotten. I certainly owe my life to Chadwick. He was persuaded to bring my mother, aged 14, with him when he first returned from Prague bringing back two boys on behalf of the school in Swanage where he taught ${ }^{18}$.

Seven more trains followed, in spite of the occupa$\operatorname{tion}^{19}$. The last train which was meant to leave Prague, on September, 1939, never departed. None of the 250 children on board was seen again. 250 families were waiting in vain at Liverpool Street that day. If the train had been a day earlier, it would have got through. Not a single one of those children was heard of again ${ }^{20}$. Most of them ended up in concentration camps. Ruth Steckelmacher's testimony recreates what happened: advised by her aunt of the cancellation of the departure of the train, she managed to escape, but those who arrived ready to take that train had to return to their accommodation. One of them was Ruza Erhmannová which served as place of transit whence to depart by train to the United Kingdom. Around forty people returned to their accommodation, their names appear in the archives of Theresienstadt ghetto, situated on the outskirts of Prague, which was a transit point to other concentration and extermination camps (Winton, 2014: 37-43).

The situation became more complicated for the British Committee for Refugee Children due to lack of funds in the summer of 1939. In July 1939, it was replaced by the Czech Refugee Trust Fund, of governmental nature. Creighton replaced Chadwick and shortly afterwards, responsibility was assumed by M.E. Guthried, as honorary secretary of the British Committee. Everything continued in accordance with Chadwick's procedure (Winton, 2014: 37). In an increasingly difficult situation both Chadwick and Warriner worked. Also Christine Maxwell, Margaret Dougan, and the Canadian Beatrice Wellington, had to leave Czechoslovakia when they realized the Gestapo were on their trail and they had to leave in a hurry. Other women who helped from Prague, like Emma Goerlich, ended up in concentration camps such as Ravensbrück.

This story of the rescue remained secret until Winton's wife, Grete, discovered a boxful of faded old documents in 1988. These were photos, lists of names of rescued children, and letters, which were given to Elizabeth Maxwell, a specialist in the study of the Holocaust, and her husband, Robert Maxwell, editor of The Mirror, who was a refugee from Czechoslovakia. On Winton's 80th birthday, a three-page article about children was published. And in 1988 the $B B C$ program That's life invited Winton, who was reunited by surprise with children he had rescued and with whom he had not kept in touch. Among them was Vera Gissing, author together with Emanuel Muriel, of Nicholas Winton and the Rescued Generation (2001).

Throughout his life, Winton continued to devote himself to philanthropic activities for the Abbeyfield extra care home for the elderly. He donated his scrapbook to Yad Vashem. William Chadwick has protested that a heroic image has been built around Winton, when Warrimer or his own father from Prague did more to rescue adults and children. However, Winton never considered himself 
to be a hero, as is apparent in his statements and the biography written by his daughter Barbara. His main objective was to get the children out of the country, because whatever happened to them in the UK with them was a better alternative to their remaining in Czechoslovakia. Without a doubt, all of them, as well as other anonymous citizens, helped to save lives.

A grown-up woman remembered the preparations and farewells of her relatives in Prague when she was six years old:

I remember very well preparing to come over to England, my mother explained it all to me, I didn't fully understand about Hitler but I just understood we had to get out. [...]. And my mother and I packed two cases, we were each allowed two. And into one she put all the family linen; there was a great deal of embroidered work, which her mother had done, very beautiful stuff. And I was able to choose my clothes and my toys and she helped me as best she could. And prepared me as best she could. She also taught me a little bit of English, but not very much, I only knew one or two phrases. I was six and a half. [...] anyway there was this nasty scene at Prague train station with all the parents seeing these children off with the labels round their necks. And I was quite excited at the beginning. And I can remember at the beginning of the journey being quite excited but gradually of course one got tired. And I do remember the train stopping and the boys got out and played ball and we girls had a picnic and I was told later that must've been in Holland. And we got to the Hook of Holland and then we got onto a boat, a very nice clean berth I remember and we arrived at Harwich in England and were taken down to London. [...] And I was just placed there. Really I suppose the main feeling was that we were waiting for my parents to arrive. And of course this was the 20th of July that I arrived so we had about five or six weeks before war broke out and of course the first thing I did was spend the first week crying day and night with dreadful home sickness. ${ }^{21}$

After the separation, begins the family fracture. The way of living this difficult experience varies according to the character of the child but also depends on the age: a small child perceives the situation in a different way from a teenager (Alted, 2003: 46-47). For teenagers, the journey represented an adventure, for many it was the first time they caught sight of the sea while accompanying and comforting the little ones. These, as can be appreciated in the preserved images of the kindertransportees ${ }^{22}$, used to carry a toy, a musical instrument or any object of attachment that connected them with their homes they had left behind with the expectation of being reunited, hence the negative impact of the news of the beginning of the Second World War that made it impossible for many parents to leave the occupied areas.

During the World War, once the programme of infant evacuations to rural areas in the United Kingdom started, Donald Winnicott together with two other psychiatrists, John Bowlby and Emmanuel Miller wrote a letter to the British Medical Journal, pointing out the dangers and psychological consequences that the evacuations entailed, especially for children under the age of five unaccompanied by their mothers (Bowlby, Miller, Winnicott, 1939: 1201-1203; Van der Horst, 2011). Connecting the separation to a higher incidence of clinical cases linked to antisocial or criminal behaviour. Apart from sadness, an emotional black-out could be triggered that would harm the development and future life of the children. Contrary to the statements of workers in children's homes who emphasised the ability of children to adapt, this happiness was, in the opinion of experts, misleading. However, as Alicia Alted points out, other studies minimize a negative impact if the children were accompanied by other siblings or adults. For parents as well as for aid associations, the primary concern was their safety.

However, the almost seven hundred children from Czechoslovakia are a small part of the ten thousand rescued through the Kindertransport and of the thousands forced to leave. Between 1933 and 1939 more than 30,000 children under 16 years fled from German-speaking areas, most of them unaccompanied by parents. Around 12,000 young Jewish people from Germany and the surrounding occupied countries emigrated in accordance with the arrangements for Youth Aliyah to Palestine. 16,000 children, the great majority of them from a Jewish background, but some from an actively socialist milieu, were assembled by the charity OSE (Organisation pour la santé et 1 'éducation) and taken to France. According to another source, there were probably over 18,000 German-Jewish boys and girls who had emigrated by the end of $1939^{23}$; while a million and a half perished as victims of the Holocaust.

\section{IDENTITIES IN TRANSIT: ARRIVAL, RECEPTION AND VITAL TRAJECTORIES}

Once they arrived at Harwich, the main port for reception of Children's transport and, to a lesser degree, in Southampton, a different path lay before the little ones. The main difference lay between those who already had a foster family in the United Kingdom and those who were sent to hostels. Owing to its proximity to the port of arrival, the most important hostel was the Dovercourt Bay Holiday Camp. It was run by the organizations that obtained the transfers. Other children found shelter in hostels, farms and schools all over Britain. As Vera Fast points out, the camps were more or less suitable for the summer, but not for the winter of 1938 to 1939, which was especially cold (Fast, 2011: 37). The children suffered from the weather conditions and had to adapt quickly to the changes involved: different country, language and customs.

The inspection reports of the Ministry of Health provide details on the facilities and situation of Central European refugees ${ }^{24}$. Regarding the Dovercourt Bay Holiday Camp, located two and a half miles from Dovercourt. A committee went to inspect the camp in December of 1938. The person in charge, Miss Essinger was away in London, and they were attended by the two doctors, one German and the other Austrian. Prominent among the 
camp staff were the volunteer teachers and who grouped children by age and taught classes in English or German.

As for the facilities that served as lodgings, they had several wooden cabins, each with capacity for 2-3 beds, with a canteen with kitchen, where kosher food was dispensed. In addition, there were bathrooms and toilets accessible to each block of cabins, usually with hot water, but during the visit, the water supply was frozen. The buildings had electric lights; the cabins used by the doctors had radiators, the same as those used by the girls for classes. The cabins near the clinic were reserved for sick children. The main room had six wood-burning stoves that, however, did no more than warm the immediate surroundings. There, they met more than 300 children. Most of them were girls, some siblings of little girls, and that day three hundred more minors were expected to arrive. With regard to their state of health, they did not seem to show symptoms of anxiety and there was one case of bronchitis and two cases of laryngitis. The clothes had been provided by Marks and Spencer, but the children felt the cold intensely. The report reveals that the camp could not be guaranteed on a permanent basis.

In another report of February 1939, after the camp was visited by a doctor, it was indicated that children under 12 years of age were seen, in general terms, to be in good condition but malnourished or shorter compared to English children of the same age, those who arrived from Vienna being in a worse state than those who arrived from Germany. This report considered that the diet provided was optimal. Most of the health problems were caused by anaemia and calcium deficiency -in another of the camps, in Lowestoft, that winter a measles outbreak had been detected- ${ }^{25}$.

In southern Wales, in Rhoose, there was another camp for refugees, on which a report was also made, in this case by the Women's Voluntary Service ${ }^{26}$. After their visit on January 16, 1939, they recommended that in order to properly care for the refugees, there was a need for at least four cooks, six maids, four janitors, one nurse and one nursing auxiliary for every 350 refugees. In cases of extended stays they would need classes to continue with their academic training, which could be an opportunity for young qualified teachers who would attend groups of ten children. Some children knew how to play musical instruments. They also recommended outdoor activities. Regarding health conditions, they insisted on a healthy diet that, in principle, seemed in accordance with their needs, and medical monitoring, with regular checks-up by the camp's medical team. There should be a permanent manager, resident manager and an assistant professor. These should stay for a period of six months or a year. Apart from central heating all year round, as well as blankets, bed linen, etcetera and adequate water supply. It was pointed out that the main inconvenience was the initial expense of the camps, fundraising involved a tremendous effort and given the expense involved in building camps, at least they counted on the existing ones throughout the country ${ }^{27}$.

At the end of March 1939, the Dovercourt camp closed, according to the annual report of the Movement for the Care of Children, and became an agricultural training centre for two hundred young people, with an instructor. A hostel for orthodox Jewish boys in Westgate was opened and most of them settled in Barham House in Ipswich. Another of the camps, established in Pakefield, Lowestoft, due to the inclemency of the weather, had to be evacuated in winter and the children distributed to other schools and hostels. According to Vera Fast it was confirmed by the press of the period that they were resettled in the Salvation Army hostel for sailors in Norwich, St. Felix School in South. And others went to Samuel Lewis Convalescent Home in Walton ${ }^{28}$.

Among the greatest difficulties detected by the Movement for the Care of Children was the race against time settle the refugees, but they thanked the Home Office, customs authorities, Railway and Shipping companies and the volunteers for the help received ${ }^{29}$.

Therefore, the children were scattered across Britain, mostly in camps and hostels under the protection of institutions and host families. The days of selection in the camps were known as "cattle days", as they chose which refugees to take to their homes. The Anglo-Jewish community tended to offer financial aid to refugees in camps rather than fostering them. For some of the refugees' parents the creed of the host family was important, for others it was irrelevant since they were non-practising. The families urged them to be on their best behaviour so that their Foster families would be proud of them. Cases varied considerably, from those in which the children did not feel a part of the family, but more like servants, in some extreme cases suffering physical violence physical violence, to just the opposite, where they were provided with a new home (Laqueur, 2004; Segal, 1964; Hammel and Lewkowicz, 2012). Although it is hard to reconstruct the lives of some ten thousand evacuees, it should be noted that some of them adapted to the country and made efforts to leave behind their own history, particularly during the Second World War. According to geneticist Gerald Wiener (2017):

Nobody could have been more anti-German than I was, from the day I arrived. I never wanted to speak German, I never wanted to know anything about Germany. I wanted to become British. I wanted to assimilate.

Some modified their surnames or were adopted, while others were reunited with their parents with work permits in the United Kingdom or emigrated again to other destinations in search of longed-for reunion:

I only stayed in England for 7 months, as my mother managed to get an American visa for me in Danzig and send it to me through friends from Belgium, which at that time was still neutral. I travelled to New York by a French ship with Kindertransport and from that point with the Greyhound buses right across America to a small village where my sister lived with her husband and their two children. I stayed with her, more or less, for a year until my parents entered the US! Approximately 10,000 children arrived in England in this way, but only $10 \%$ of these children saw their parents again. $[\ldots]$ I was one of these "privileged" children. ${ }^{30}$ 
Her parents endured an odyssey until they had the possibility of reaching Cuba via Italy and Spain. In Cuba, they had to wait a year to obtain the visa for the US, where the encounter took place.

Another crossroads scenario was in France, where Jews arrived, fleeing Nazi persecution. In France, the Jewish population amounted to approximately 300,000, of which about 200,000 resided in Paris and some 50,000 moved south in search of safer places (Bankier and Gutman, 2005). Since the German occupation the first measures against Jews were taken by means of the census, which was the basis for their later persecution. In the occupied area, the Jews were forced to wear the Star from the $19^{\text {th }}$ of May $1942^{31}$. In October 1940, the first statute of the Jews was created in the "free zone"; the new legislation stipulated that they should not have access to different types of jobs in administration, education, the media and the cinema. In June 1941 the second statute was promulgated, tougher than the first with the exclusion of Jews from University and freelance professions. These days witnessed the first roundups of Jews and in January 1942, German authorities met to decide and plan "the final solution to the Jewish problem". The rafle du Vel' d'Hiv'occurred from the 16 to 17 of July of 1942, where many women and children crowded in terrible conditions. From there they were deported to concentration camps and driven to extermination. According to Robert Paxton (Marrus and Paxton, 1995; Paxton, 2015), the French administration played an active role in the repression against the Jews. The final balance of the extermination of 25 per cent of the Jews who were living in France would have been much greater had it not been for a good number of French citizens who showed great courage in hiding Jews and helping them escape throughout France. This is the case of Kurt Fuchel's parents, who had been concealed. At the end of the war, he discovered that his parents were alive and that one day he would have to go back and live with them. As he recounts:

\begin{abstract}
.... I think I was horrified by that idea. 'Uncle Percy' persuaded my parents to wait until I'd finished the English School Certificate at age 16. And also they needed time to re-establish themselves. Eventually, in 1947, they were ready for me. I did not want to go but the Cohens took me to Paris... where I was to meet my parents. I remember standing outside the hotel. And I saw, in the distance, my parents approach. I could not look at them directly. So I looked at their reflection in a shop window... as they walked towards me. I felt... a very, very strong emotion. It was a sense of elation and love... I suddenly felt it and fought it. But I felt, you know, I knew it was them. ${ }^{32}$
\end{abstract}

As his foster mother relates, Kurt's father, who was more expressive than his mother, ran his hand through Kurt's curly hair and Kurt pulled away from him. At this gesture his stepfather rebuked him: "never do that again, Kurt. Your father is showing you affection". For Kurt the farewell of his host family, the Cohens, helped him to realise that they had really loved him. Especially his Foster father 'Uncle Percy', whom nobody before had seen crying. Regarding the British legislation on legal adoption, at that time it was complicated, the restriction becoming less severe after the war $^{33}$. Most of the children who arrived from the Kindertransports were orphaned. Kurt's case was different because he had two families: the foster family and the biological family. All of a sudden, when he saw his parents he found that his parents had become strangers, unfamiliar beings:

My parents let go a 7-year-old child and got back a 16-year-old. And my mother, especially, wanted to carry on where she had left off. And a 16 year-old does not like to be treated like a 7 year-old. So when we got back to France, things were very difficult. Of course, I am very lucky. I realize this. Whereas most of the kinder never saw their parents again. I not only had mine back, but another set of parents as well. What more could one ask for? $?^{34}$

Both testimonies show the key role of France as a place of refuge, of departure to other destinations and especially of reunion. To keep in touch with their families there were written letters through the Red Cross. This is the case of Irene Borchardt, who received correspondence from her mother before the end of the $\operatorname{war}^{35}$; to find out about the whereabouts, in most cases meant the end of hope, as they were notified of the death, as is reflected by the testimonials collected in the documentary Into the Arms of Strangers:

I wrote separate letters because I had separate addresses through the Red Cross messages in Theresienstadt. The letters were returned to me about three or four months later. It took a long time. All it said on the back was: deported to Auschwitz... October, '44 and war finished in May '45 That's how I found it. ${ }^{36}$

After hearing the sad news, it was necessary to assemble the pieces and to continue with their lives. And so they did via their different professions and with their activism, contributing in the host countries, as is shown in the next section.

\section{THE LEGACIES. KINDERTRANSPORT ASSOCIATION, MEMORIALS AND THE CULTURE OF HUMANITARIAN AID}

Many years later, Bertha Leverton, a "kind" who arrived in Great Britain thanks to the Kindertransport, organised a reunion in 1988, on the occasion of the fiftieth anniversary of the arrival in the United Kingdom. The event involved the reunion of many evacuees from different countries. A year later, Eddy Behrend from New York took up the baton and together with other "kinder" launched the Kindertransport Association (KTA), whose goal was to: share their stories, honour those who made the Kindertransport possible and support charitable work that aids children in need. This is an association promoting exhibition, conferences and is, at the same time, a learning platform of resources and an intergenerational bridge. 
In the fields of literature and drama, the experiences of the Kindertransport children have been reflected. One of the most emblematic works is a play entitled Kindertransport written by Diane Samuel, which since it was premiered in 1993 at the Cockpit Theatre in London has had a long history. For the author, the work is about:

The question of how human beings survive after they have suffered deep emotional trauma and how the damage caused is passed onto the following generation. Also, at its heart, the play is about that universal and timeless aspect of human experience: the separation of a child from its parent. Every person on earth, whatever their age, can relate to that ${ }^{37}$.

There have been paths through life, as many as there are human beings behind the statistics. Many have contributed to the foster society and felt this to be their duty. This is how Eve Leadbeater expresses it: "I hope I have repaid some of my debt to this country by teaching children in secondary schools and working as a charity volunteer in my retirement. ${ }^{38 "}$ Another of the children who was rescued was the geneticist Gerald Wiener (Dunlop, 2016; Rampen, 2017), who has developed an international recognised career. Among the most well-known 'children of Prague' are the journalist Joe Schlesinger (Elek, 2011) and the poetess Gerda Mayer. ${ }^{39}$

On a tour of the places of memory of the Kindertransports, we would be led to a sculpture in the Wilson station of Czechoslovakia with Winton and a little child as protagonists and also to the place of arrival in London, Liverpool Street station and in particular, to Hope Square, where one can see a sculpture of a group of boys and girls of different ages, disoriented, with luggage and identification badges, with the plates of different points of departure from Central Europe from where they arrived in the United Kingdom via the children's transports. In the British Parliament there is also a testimonial plaque from the protagonists in gratitude for contributing to saving the lives of some ten thousand children.

To the aforementioned places should be added the platforms of museums or the most recent, created by the Joint Council for the Welfare of Immigrants "I am a refugee" 40 that launched a campaign on the $20^{\text {th }}$ of June 2016 to commemorate World Refugee Day and celebrate the contributions that the refugees, irrespective of their origin, had made in the foster society "It reminds the public that those who are given sanctuary give so much back in return". And on their website one can see the plaque dedicated to Dame Stephany Shirley, rescued by means of the Kindertransport and her valuable contribution as "computer pioneer and philanthropist”' (Shirley, 2017).

In conclusion, the humanitarian actions of individuals, organizations and institutions connect past and present, given that the need to evacuate children and young people from armed conflict or high-risk areas was and is a reality, then and now. The experience of these actions in the thirties and forties is part of the history of humanitarian aid. Concerning the Kindertransports there is still much to be learned, because the trajectories of these young people were lost through different countries, their experiences are very different, within the childhood experiences of exile on which comparative studies are needed. The misfortunes in their lives were not only marked by separation and the need to adapt to wherever they were, but to live and overcome their traumatic memories which still do not contemplate the most vulnerable, those who undertook the route with disabilities. Some of their members because of their professional career were more visible, others in turn, live anonymously. The Association created keeps alive memory and intergenerational dialogue so as to learn from past experiences and help in the present.

The European Parliament resolution of 2 April 2009 on European conscience and totalitarianism calls for the recognition of all victims of totalitarian regimes and respect for human rights, to keep memory alive. In this regard, the value of studies in history is crucial as learning from situations of intolerance and extreme racism in the face of anti-Semitic laws and loss of citizenship. The destiny of both children and adults was forced labour and extermination, but the other side of this situation was the aid activities for the evacuation, the organization of the Kindertransports, which succeeded in moving thousands of children from Central Europe, occupied by the Nazis, to Great Britain and the welcome in the country, as more human and redeemable facets of those times of panic and uncertainty. Despite the difficulties, many left aside their safety and affluent life: Winton, for instance, who cancelled a holiday to know first-hand the situation of the refugees in Czechoslovakia and become actively involved; he is probably the most recognised activist due to a myriad circumstances, but especially, thanks to the media campaign after appearing in the Daily Mirror, forming a mythical image with which he did not identify and this focus seems to detract from the relevance of other philanthropists, but, as Talmud the observes, "Whoever saves a life, saves the entire world" and it shows us that even in the most difficult moments, of governmental passivity - although the involvement of the British government is remarkable-, after a failed conference like that of Evian and where everything seemed lost, the courage of people lit a path for a possible future. To ensure that these experiences are not forgotten, the Kindertransport Association, the protagonists themselves and their descendants, the media, teachers and historians are carrying out a new task of rescue of knowledge and inter-generational links to promote a culture of humanitarian aid.

\section{ACKNOWLEDGMENTS}

This article forms part of a project undertaken thanks to the research programme: 'Ayuda humanitaria europea en Francia durante la Segunda Guerra Mundial' (European Humanitarian Aid in France during the Second World War); Reference: HAR2014-58043-P funded by Ministerio de Economía y Competitividad, Gobierno de España. 
I am extremely grateful to Natascha Schmöller, Paul Preston and Michel Alpert for their generosity and to the Cañada Blanch Centre (LSE) for the facilities and support offered to me during the time I spent there on a research visit.

\section{NOTES}

1 See The National Archives [TNA], Foreign Office [FO], 919/5. Leaflet, reports and correspondence relating to the Evian Conference, held by the League of Nations to explore possible approaches to the resettlement of central European Jews after the rise of the Nazis.

2 House of Commons Hansard Archives [HC], Debates. 21 November 1938 vol 341 cc1313-7.

3 See also London Metropolitan Archives. British Fund for World Jewish Relief

4 See http://www.yadvashem.org/ [accessed 28/June/2017].

5 Minutes of the War Cabinet Legislation Committee and a copy of the Guardianship (Refugee Children) Bill draft; documents from the Education Department \& Board of Education on the problems faced by gifted Jewish Kindertransport schoolchildren progressing to higher education facing financial problems.

6 See http://www.kindertransport.org/ [accessed 28/June/2017].

7 See also other audiovisuals Elek (2011); Mináč (1999 and 2002).

8 Testimony of Ursula Rosenfeld (Ursula Ellen Simon) in Harris (2000) Into the Arms of strangers.

9 According to Holocaust Encyclopedia: Jewish organizations inside the Greater German Reich planned the transports. These organizations were the Reich Representation of Jews in Germany, headquartered in Berlin; after early 1939, its successor organization the Reich Association of Jews in Germany; and the Jewish Community Organization (Kultusgemeinde) in Vienna. They generally favored children whose emigration was urgent because their parents were in concentration camps or were no longer able to support them. They also gave priority to homeless children and orphans. For further information see United States Holocaust Memorial Museum:

https://www.ushmm.org/wlc/en/article.php?ModuleId=10005260 [accessed 17/July/2017].

10 Doreen Warriner (1904-1972) Academic from University College London. Her voluntary work, helping refugees escape from Czechoslovakia, earned her an OBE.

11 Assisted by donations from non-government bodies, like the Lord Mayor of London's fund, the British Committee for Refugees from Czechoslovakia (BCRC), later the Czech Refugee Trust Fund was set up, putting in place the apparatus to bring emigrants to Britain. One advantage of the financial involvement of the government was that H. M. Treasury sent Robert Stopford to Prague in October 1938 as its representative. Grenville (2011)

12 British Library (BL). The National Life Story Collection. The Living Memory of the Jewish Community. Nicholas Winton. O.B.E. interviewed by Milenka Jackson. C410/094/01-03 14th August 1990.

13 Nicholas George Wertheim was born in London, England, on May 19, 1909. He was the oldest of three children whose parents, Rudolf and Barbara Wertheimer, were German Jews who later converted to Christianity and changed their last name to Winton. Young Nicholas grew up with considerable means. Winton followed in his father's footsteps and apprenticed in international banking. Afterward he worked in banks in London, Berlin and Paris. In 1931 he returned to England and began his career as a stockbroker. Organized the rescue of 669 Jewish children from Czechoslovakia at the dawn of World War II. He was knighted in 2003 and died on July 1, 2015, at the age of 106.

14 British Library (BL). The National Life Story Collection. The Living Memory of the Jewish Community. Nicholas Winton. O.B.E. interviewed by Milenka Jackson. C410/094/01-03 14th August 1990.
15 Trevor Chadwick (1907-1979). He graduated in 1928. He joined the Colonial Office and was posted to Nigeria as a district officer. He got married in 1931, left the Service and worked as teacher in the family school. Many appeals for sponsorship circulated in the 1930's. One arrived on the desk of Rev. R. M. Chadwick, who decided to take two boys to the school and Chadwick and Phelps flew to Prague. They took three children, one of them a girl, Gerda Mayer, who became a poet. He offered to come out to help till June. After war was declared, he joined the Royal Navy, later Royal Air Force. He did various jobs became critically ill with tuberculosis. He settled in Norway till his retirement in Southampton. (William, 2010: 64-86).

16 See http://www.nicholaswinton.com/WintonsList/children.htm [accessed 22/July/2017].

17 Other collaborating organizations were Boys Scouts International, Trades Union Congress, YMCA, Woodcraft Folk, Salvation Army.

18 Letters. Forgotten heroes of the kindertransports, The Guardian, Friday 3 July 2015.

19 According to The Movement for the Care of the Children from Germany Ltd. British Inter-Aid Committee. Czech Section Bloomsbury ST. Report 'B' 2nd October 1939. Statement of children brought over up to the 1st September 1939. Transport from Prague: 14th March 1939 -20; 19th April -36; 29th April29;13th May 61; 2nd June -123; 1st July - 241; 20th July-76; 2nd August- 68; Various transport from Vienna, etc. - 15. Total: 669. 561 Jewish, 52 Unitarian, 34 Roman Catholic, 17 without confession (Winton, 2014).

20 See for further information http://www.intothearmsofstrangers. $\mathrm{com} /$ [accessed 27/July/2017].

21 British Library. BL. Living Memory of the Jewish Community. Anonymous interviewed by Gaby Glassman in 1988. Ref. C410/007.

22 See collections from The Viewner Library, based in London, a continuously developing library, archive and information service for the UK and for the international community, dedicated to supporting research, learning, teaching and advocacy about the Holocaust and genocide, their causes and consequences.

23 These statistics relate partly to children from Germany and Austria only, partly to those from German speaking countries and areas, including Czechoslovakia, and partly to countries occupied by the National-Socialist regime. Despite the facts, it is impossible to reach a clearer picture because of the unavailability of records or the lack of clarity in those sources which are available. Kroger (2004: 8-20).

24 TNA. Ministry of Health [MH] 55/689. Jewish Refugee Camp, Dovercourt Essex, visited 19th December 1938 by C.F. Roundel, Chief General Inspector, accompanied by Miss Montagnon, Woman inspector.

25 TNA. MH 55/689. Jewish Refugee Camp, Dovercourt Essex, visited 7th February 1939, by Doctor P.P. Fox, Medical Officer of Health of Harwich. Medical report, 15th February 1939.

26 A voluntary organisation concerned with helping people in need throughout England, Scotland and Wales. It was founded in 1938 by Stella Isaacs, Marchioness of Reading. Beauman, Katharine Bentley (1977) Green Sleeves: The Story of WVS/ WRVS. Seeley Service \& Co, London.

27 TNA. MH 55/689. Women's Voluntary Service. Report on a visit. 16th January 1939.

28 Children evacuate Lowestoft camp safeguard against intense Cold. Jewish Chronicle, 23rd December 1938: 18

29 TNA. Home Office [HO] 213/302. Movement for the Care of Children from Germany Ltd -Inter-Aid Committee for Children and Children's Section of the British Committee for Refugees from Czechoslovakia. The Annual Report 1938-1939.

30 Ilse Hadda, interviewed, in 2012, by Natascha Schmoeller, who translated her testimony into Spanish. I am very grateful for her help.

31 USC Shoah Fondation. University of South Carolina. "Être juif en France, expériences vécues de la persécution: Le port de l'étoile jaune." 
32 Testimony of Kurt Fuchel in Harris (2000) Into the Arms of strangers.

33 Hansard, HCD, vol. 3439 of February1939, quoting The Adoption Children Act 1926.

34 Kurt Fuchel's testimony in Harris (2000) Into the Arms of strangers.

35 Yad Vashem Digital Archive. Her mother wrote her on 8th December 1941, and was replied by Irene on the reverse side of the letter, 04 February 1942. Irene received another letter from her mother and sister, Lilli on 14th October 1942. Her parents were Jacques Borchardt and Franziska Frida (Pasmantier) Borchardt; her siblings were her brother Helmut Michael, born in1923, and her sister Lilli Flora, born in 1926; Irene left Germany on a Kindertransport at the age of 10 and arrived to England in May in 1939; her siblings did not succeed in arriving to England because foster families could not be found for them; Irene was the only one who was chosen; Irene received information after the war, and she found out that all of her family was murdered in Riga.

36 Lorraine Allard's testimony in Harris, J. (2000) Into the arms of strangers.

37 See http://www.sharedexperience.org.uk/media/education/kindertransport edpack.pdf [accessed 7/August/2017].

38 Kindertransport hero's daughter urges UK to welcome Calais refugees. The Guardian, Saturday 26th October 2016.

39 A Jewish girl who was rescued from Prague by Trevor Chadwick in 1939 (Chadwick, 2011).

40 Created by The Joint Council for the Welfare of Immigrants (JCWI), an independent national charity established in 1967.

\section{REFERENCES}

Alted, Alicia (2003) "Los niños de la Guerra Civil". Anales de Historia Contemporánea, 19: 46-47.

Bankier, D., y Gutman, I. (2005) La Europa nazi y la Solución Final.Madrid: Losada Editorial.

Bowlby, J, Miller, E., Winnicott, D.W. "Evacuation of Small Children". The British Medical Journal, 16 December 1939: 12011203.

Breitman, Richard, Kraut, Alan M. (1987) American Refugee Policy and European Jewry, 1933-1945. Indiana University Press.

Chadwick, William R. (2010) The Rescue of the Prague Refugees 1938/39. Matador, Leicester.

Dunlop, Margaret M. (2016) Goodbye Berlin: The Biography of Gerald Wiener. Birlinn Ltd.

Emanuel, Muriel, Gissing, Vera (2001) Nicholas Winton and the Rescued Generation: Save One Life, Save the World. Vallentine Mitchell.

Fast, Vera (2011) Children's Exodus: A History of the Kindertransport. I.B. Tauris, London.

Febvre, Lucien, "La sensibilité et l'histoire: Comment reconstituer la vie affective d'autrefois?". Annales d'histoire sociale, 3, 1941: 5-20
Gershon, Karen (1966) We came as children. A Collective Autobiography of Refugees. Victor Gollancz.

Grenville, Anthony (2011) "Doreen Warriner, Trevor Chadwick and the "Winton children"'. AJR Journal, volume II 4: 1

Hammel, Andrea and Lewkowicz, Bea (eds.) (2012) The Kindertransport to Britain 1938/39: New Perspectives. Rodopi, Amsterdam

Kroger, Marianne (2004) "Child Exiles: A new Research Area?" Shofar: An Interdisciplinary Journal of Jewish Studies, Volume 23, 1: 8-20.

Laqueur, Walter (2004) Generation exodus. The fate of Young Jewish Refugees from Nazi Germany. IB Tauris, London.

Marrus, Michael R. and Paxton Robert O. (1995) Vichy France and the Jews. Standford University Press.

Paxton, Robert "Vichy et les juifs", 20th October 2015 France info. Recuperado de http://www.franceinfo.fr/emission/lelivre-du-jour/2015-2016/robert-paxton-vichy-et-lesjuifs-20-10-2015-09-38 [accessed 28/June/2017]

Plamper, Jan (2013) "L'histoire des émotions", in Christophe Granger, ed. À quoi pensent les historiens? Faire de l'histoire au XXIe siècle. Paris: 225-249.

Rampen, Julia "From the Kindertransport to Dolly the Sheep: a New Statesman subscriber's story”. New Statesman, 21st June 2017.

Roth, Milena (2004) Lifesaving letters: A Child's Flight from Holocaust. Unversity of Washington, Washington.

Segal, Lore (1964) Other People's House. Harcourt, Brace \& World, New York.

Shirley, Dame Stephany (2017) Let It Go: The Memoirs of Dame Stephanie Shirley. Andrews UK Limited.

Van der Horst, Frank C.O. (2011) John Bowlby. From Psychoanalysis to Ethology: Unravelling the Roots of Attachment Theory. Wiley-Blackwell.

Wiener, Gerald "I wanted to be British". The Times, 27th January 2017.

Williams, Frances Mary (2012) Kindertransport to Scotland: reception, care and resettlement. The University of Edinburgh, Edinburgh.

Winton, Barbara (2014) If something is not impossible... The life of Sir Nicolas Winton. Troubador Publishing.

Zaragoza Bernal, Juan Manuel (2013) "Historia de las emociones: una corriente historiográfica en expansión”. Asclepio, 65 (1): e012, doi: http://dx.doi.org/10.3989/asclepio.2013.12

\section{Audiovisuals}

Elek, Judit (2011) Nicky's family. Trigon Productions, WIP

Harris, M. J. (2000) Into the Arms of Strangers: Stories of the Kindertransport. U.S. Holocaust Memorial Museum, Sabine Films, Skywalker.

Mináč, Matej (1999) All My Loved Ones. Agencja Produkcji Filmowej, Ceská Televize, in Film Praha.

Mináč, M. (2002) Nicholas Winton: The Power of Good (Sila lidskosti: Nicholas Winton). Ceská Televize, Horizont Solvakia, Solovenská Televízia, et alii. 